\title{
Early changes in farmers' adoption and use of an improved maize seed: An assessment of the impact of demos and field days
}

\begin{tabular}{|c|c|}
\hline $\begin{array}{l}\text { Authors: } \\
\text { Mercy W. Kam } \\
\text { Fredrick Bagar } \\
\text { Claris Riungu }{ }^{1} \\
\text { John Mukund } \\
\text { Robert Toel }^{1}\end{array}$ & $\begin{array}{l}\mathrm{au}^{1} \mathbb{1} \\
\mathrm{nba}^{2} \mathbb{1}\end{array}$ \\
\hline \multicolumn{2}{|c|}{$\begin{array}{l}\text { Affiliations: } \\
{ }^{1} \text { Tegemeo Institute of } \\
\text { Agricultural Policy and } \\
\text { Development, Egerton } \\
\text { University, Kenya }\end{array}$} \\
\hline \multicolumn{2}{|c|}{$\begin{array}{l}{ }^{2} \text { Department of Agri-business } \\
\text { and Natural Resource } \\
\text { Economics, Makerere } \\
\text { University, Uganda }\end{array}$} \\
\hline \multicolumn{2}{|c|}{$\begin{array}{l}{ }^{3} \text { Development Economics } \\
\text { Group, Wageningen } \\
\text { University, the Netherlands }\end{array}$} \\
\hline \multicolumn{2}{|c|}{$\begin{array}{l}\text { Corresponding author: } \\
\text { Mercy Kamau, } \\
\text { mkamau@tegemeo.org }\end{array}$} \\
\hline \multicolumn{2}{|c|}{$\begin{array}{l}\text { Dates: } \\
\text { Received: } 20 \text { Aug. } 2017 \\
\text { Accepted: } 14 \text { Feb. } 2018 \\
\text { Published: } 28 \text { June } 2018\end{array}$} \\
\hline \multicolumn{2}{|c|}{$\begin{array}{l}\text { How to cite this article: } \\
\text { Kamau, M.W., Bagamba, F., } \\
\text { Riungu, C., Mukundi, J. \& } \\
\text { Toel, R., 2018, 'Early changes } \\
\text { in farmers' adoption and use } \\
\text { of an improved maize seed: } \\
\text { An assessment of the impact } \\
\text { of demos and field days', } \\
\text { African Evaluation Journal } \\
\text { 6(1), a278. https://doi.org/ } \\
\text { 10.4102/aej.v6i1.278 }\end{array}$} \\
\hline \multicolumn{2}{|c|}{$\begin{array}{l}\text { Copyright: } \\
\text { ( 2018. The Authors. } \\
\text { Licensee: AOSIS. This work } \\
\text { is licensed under the } \\
\text { Creative Commons } \\
\text { Attribution License. }\end{array}$} \\
\hline \multirow[b]{2}{*}{ 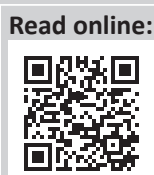 } & \\
\hline & $\begin{array}{l}\text { Scan this QR } \\
\text { code with your } \\
\text { smart phone or } \\
\text { mobile device } \\
\text { to read online. }\end{array}$ \\
\hline
\end{tabular}

Authors:

Affiliations:

Tegemeo Institute of

Development, Egerton

University, Kenya

${ }^{2}$ Department of Agri-business

and Natural Resource

Economics, Makerere

${ }^{3}$ Development Economics

Group, Wageningen

Corresponding author:

Mercy Kamau,

Dates:

Received: 20 Aug. 2017

Accepted: 14 Feb. 2018

mba, $F$

in farmers' adoption and use of an improved maize seed:

African Evaluation Journal

6(1), a278. https://doi.org/

Copyright

(C) 2018. The Authors. Licensee: AOSIS. This work

(1) to read online.
Background: Demonstration plots are widely used in the seed industry to create awareness and promote improved seed among smallholder farmers in sub-Saharan Africa. However, the magnitude of effects on farmers' adoption behaviour is less known.

Objectives: This study assessed the impact of demonstration plots and field days on farmers' awareness, knowledge and use of the improved maize variety that was being promoted. The study also assessed the impact on maize yields and production.

Method: A promotion campaign was mounted by a local seed company in eastern and western Uganda, where demonstration plots were established and field days were held for two seasons. These were aimed at augmenting effects of radio messages that were aired over the same period. We used quasi-experimental approaches to determine changes in farmers' adoption behaviour towards a new maize variety, and the subsequent effects on productivity. Farm household data were collected at the baseline and midline from a sample of 2050 households.

Results: The findings showed no effect on the proportion of farmers planting the promoted variety, the acreage or proportion of land planted with the promoted variety. This was not surprising as farmers' awareness and knowledge about the variety remained very low.

Conclusion: The early result shows that demonstration plots were not effective, suggesting that more effective approaches should be explored. It may also be the case that the assessment was too early in the adoption cycle, in which case results after two more seasons of promotion will provide a better estimate of the effect.

\section{Introduction}

\section{Background}

The consequences of low and stagnated agricultural productivity in sub-Saharan Africa (SSA) have been poverty and food insecurity. Improved seed usage is one of the pathways being followed to sustainably improve agricultural productivity; however, farmers in SSA have a limited choice of improved varieties of seed (AGRA 2013), and most of them plant land races or varieties that have been in circulation for more than three decades (Hassan 1998). Recent studies have shown that it is not the adoption of maize hybrids per se which determines the effect of improved seed on maize productivity, rather the replacement of the old with new varieties (Smale \& Olwande 2011). This means that production and distribution of newly released improved seed varieties, farmer awareness about them, access to and use of the new improved seed varieties are important prerequisites to increasing agricultural productivity through crop improvement.

The challenge facing agencies that seek to increase agricultural productivity through crop improvement is, therefore, not only how to increase the use of improved varieties but also how to speed up the adoption process among smallholder farmers including women farmers. There are multiple methods available that are used by seed companies, government and non-governmental agencies to market and create awareness or promote new seed varieties; yet studies on adoption of new varieties show that many farmers in SSA have not been reached or are not using improved seed.

Awareness creation and promotion methods are premised on the assumption that farmers are more likely to adopt new varieties after witnessing outcomes, for example from demonstration plots, field days, own plots or plots of neighbours and friends. 


\section{Problem statement}

Publicity efforts to enhance adoption of new seed varieties in the region are rarely supported with evidence of the efficacy of the various awareness creation and promotion approaches or modalities that are commonly applied. The situation is well captured by a recent report by the independent science and partnership council of the Consultative Group for International Agricultural Research (CGIAR), which describes the situation in awareness creation and seed promotion in the following manner: 'the likely effectiveness of measures employed to enhance farmer awareness and access to seed are "vague and their likely effects questionable"'. This study therefore evaluates the effects of an awareness creation and seed promotion method that is commonly used by seed companies in SSA, namely demonstration plots and field days. Using quasiexperimental approaches, changes in adoption behaviour of households in a treated geographical area were compared with changes in households in an untreated but comparable geographical area.

The awareness creation and promotion campaign involved augmenting radio adverts and talk shows with demonstration plots and field days. This approach was expected to induce significantly greater adoption of the variety being promoted, compared with areas where only radio adverts and talk shows were aired. The hypothetical question in this study is therefore, 'what would have happened to the awareness and adoption behaviour of individuals and households if the radio promotions had not been augmented with demonstration plots and field days?' The study seeks to:

- determine whether farmers' awareness, perception, attitude, knowledge and use of the improved variety changed following the promotion campaign which was mounted for two growing seasons, and whether male and female farmers' behaviour was influenced by the promotion campaign

- determine whether the promotion campaign had an impact on maize yield and production.

\section{Literature review}

Farmers are not likely to take up new technologies when they have little or no information about how the technology works, the magnitude of benefits from its use and the risks involved. Yet there are few studies on the influence of sources of information (Adesina \& Baidu-Forson 1995; Knowler \& Bradshaw 2007) on agriculture technology uptake. Effective extension methods involve adequate and timely access by farmers to relevant information and advice, with appropriate incentives to adopt the new technology. The extension method should also be efficient in resource utilisation so as to optimise the adoption process.

Various extension methods are used to create awareness about improved technologies. Agricultural extension officers are mostly relied on to disseminate information to farmers and farmer trainings, farm visits and agricultural shows are the approaches commonly used by the extension agents (Musa, Aboki \& Audu 2013). However, information dissemination through these methods is limited because of high transportation costs and poor infrastructure normally makes it difficult to reach farmers in remote areas, and often most farmers do not avail themselves for training and visits (Adeola 2005). In some cases, lead farmers are used to disseminate information. They train other farmers, provide advice and monitor how other farmers use technologies being promoted (Khaila et al. 2015). This approach is preferred because it can reach more farmers at a lower cost, and there is a high level of trust by other farmers. In this approach, farmers who are comparable with target farmers are more likely to influence the adoption behaviour of their peers (BenYishay \& Mobarak 2013).

More modern approaches rely on information and communication technologies (ICTs) to disseminate agricultural information (Zhang, Wang \& Duan 2016). The commonly used approaches are web portals, for example M-Farm, call centres and use of short text messages (SMS) and mobile Internet-based price information (Munsaka 2010; Solon 2013). Farmers access information on inputs availability and market information without travelling long distances. Costs of data, limited access to Internet, computers and mobile phones especially in poor rural households are a major setback to reaching the poor using these approaches.

Demonstration plots, farmer field schools (FFS), field days, radio adverts, leaflets or brochures have over time been the most commonly used approaches in disseminating information to farmers. FFSs have been shown to positively impact production and income (Davis et al. 2012; FriisHansen \& Duveskog 2012; Kabir \& Uphoff 2007; Van den Berg \& Jiggins 2007). However, some studies, such as Waddington et al. (2011), found there was no productivity improvement in Ethiopia where FFS was a leading extension method. Mass media, print media, opinion leaders and extension workers have all been used to create awareness and disseminate new agricultural technologies (Ghatak 2010; Mgbakor, Iyobor \& Okezie 2013; Nazari \& Hasbullah 2010). Demonstration plots and field days are preferred because they not only create awareness about modern technologies but also motivate farmers to apply them in their farms (Khan et al. 2009; Kondylis \& Mueller 2013). In spite of their positive attributes, only a few studies have focused on the effectiveness of demonstrations as an extension method (Khan et al. 2009) and field days as a dissemination tool (Amudavi et al. 2009; Carolan 2008; Heiniger et al. 2002), and most have used crosssectional and non-experimental designs.

\section{Research method and design}

Two relatively different approaches were used by a private seed company to create awareness and promote a new maize variety, PH5052, and a research team designed an impact evaluation study that would inform the selection of seed promotion strategies. In some areas, the seed company mounted a campaign through the mass media only, where 
messages about new varieties were aired through radio adverts and talk shows. These areas were assigned to the 'control group'. In other areas, the seed company mounted a campaign through the mass media and also established demonstration plots and held field days. The areas were assigned to the 'treatment group'. The promotions were mounted for two consecutive cropping seasons in both the treatment and control areas.

\section{Assignment of the demonstration plots and radio promotions}

The awareness creation and promotion campaigns were conducted in four districts: Hoima and Masindi in mid-west Uganda and Iganga and Tororo in eastern Uganda. These maize producing areas were considered suitable for an evaluative study because the seed company had not promoted the maize variety PH5052 in the area before. The following strategy was followed in assigning the study areas to treatment and control groups. Firstly, from a list of all subcounties in the four districts, four sub-counties were randomly chosen from each district to get a total of 16 subcounties, which formed the study area. Only sub-counties where crop production is the mainstay were included as subcounties falling in the oil zone or the cattle corridor (Kyangwali and Buseruka) or in municipal councils were dropped from the list. Secondly, two out of the four subcounties in each district were randomly chosen to form the 'treatment' group, where demonstration plots were established and field days were held in addition to radio adverts and talk shows. The remaining two sub-counties in each district formed the comparison or 'control' group, where only radio adverts and talk shows were aired. Table 1 provides the list of the randomly selected 16 sub-counties and the group they were assigned to.

Demonstration plots were randomised at sub-county level, with each county in the treatment group being assigned a demonstration plot and field day. Baseline results show that farmers mainly rely on interpersonal communication for information on improved farming practices, and they consult

\begin{tabular}{lll} 
TABLE 1: Study areas. & & \\
\hline District & Sub-county & Group \\
\hline Hoima & Kyabigambire & Treatment \\
& Kitoba & Control \\
& Kiziranfumbi & Treatment \\
& Bugambe & Control \\
Masindi & Pakanyi & Treatment \\
& Bwijanga & Control \\
& Mirya & Control \\
& Karujubu & Treatment \\
Iganga & Nambale & Treatment \\
& Makuutu & Control \\
& Igombe & Treatment \\
& Nawandala & Control \\
Tororo & Mulanda & Control \\
& Molo & Control \\
& Kirewa & Treatment \\
& Nagongera & Treatment \\
\hline
\end{tabular}

other farmers who reside not more than $5 \mathrm{~km}$ away from them. With one demo plot in a sub-county, the chances of non-compliance or contamination were minimal. It is important to note that while randomisation was at the subcounty level, the unit of analysis in the impact evaluation was the farm household and individuals within the households falling within sub-counties in the 'treatment' group, while comparison farmers were households or individuals in households falling within sub-counties in the 'control' group.

\section{Selection of demo sites and demo hosts}

According to the implementing agency (private seed company), demonstration plots must be located in sites where there is the greatest chance of contact with targeted farmers. The sites that are considered to be suitable are farms or plots along major roads in terms of the volume of passersby such as along tarmac roads farms next to market places. Literature on agricultural transformation shows that there are hard-to-reach groups such as the poor households and women farmers. One of the objectives of the study was to determine whether such groups were reached and influenced by the seed promotion campaigns mounted by the seed company. Therefore, upon insistence of the evaluation team, the demo sites were placed along rural roads which were much nearer to the farmers' fields and homes although this was against the better judgement of the seed company.

Once potential demo sites had been identified, the seed company had to approach the would-be hosts (farmers). After explaining the purpose of demo and the implementation plan, potential hosts were asked whether they were willing to host or serve as demo hosts. Two demonstration farms were selected in each sub-county in the 'treatment' group to give a total of 16 demonstration farms.

\section{Non-compliance of participants}

Farmers in the control group are likely to travel to the treatment areas where the demo plots were established, in which case the control group would no longer serve as a true counterfactual or comparison group. This 'non-compliance' threatens the integrity of randomisation if the individuals are self-selecting into the two groups. In this study, the likelihood of non-compliance was minimised by the following: firstly, randomisation at the sub-county level, which is a large administrative area, was done, thus ensuring a reasonable separation of treatment and control areas; secondly, one of the baseline findings was that farmers in the study areas mainly consult others within their village and do not travel beyond $5 \mathrm{~km}$ for consultation about improved farming practices.

\section{Evaluation method Analytical approaches}

Although several empirical approaches are often used to assess changes that occur following an intervention, not all 
are reliable where one needs to attribute changes to specific interventions. In this evaluative study, we have used two approaches: difference in differences (DiD) with matching and doubly robust estimation; therefore, the article also serves to demonstrate how findings can vary when the wrong methods are used.

\section{Comparability of treatment and control groups}

In this section a discussion of some of the important considerations when choosing an analytical approach during impact evaluations is presented. The first is whether the treatment group and the control group are comparable prior to or at the onset of the intervention. A randomisation check may be undertaken to check whether the observed factors or variables in the treatment and control group were the same at the baseline. A balance test $t^{1}$ was used to test whether the randomisation created balance on various characteristics across experimental conditions (Mutz \& Pemantle 2011). Clustered standard errors (village cluster) were used in the balance test because most observations are affected uniformly within a group (village) rather than individually. The clustered standard errors increase confidence interval because it allows for correlation between observations (Green \& Vavreck 2008; Hartman \& Sp 2010). The results indicated that the households in the two groups differed along important characteristics, namely wealth and distances to infrastructure or facilities, with households in the treatment group being wealthier and falling closer to market-related facilities. This implies that the treatment and control groups were not similar in most of the observable characteristics at the baseline.

The result suggests that randomisation of the intervention was not successful and that there was 'self-selection' into the treatment group. The other cause would be the inherent weakness in the design of the intervention in that it could not isolate households that would actually be reached by the demonstration plots and field days. Administrative boundaries delineated treatment areas.

When there are unobserved factors influencing outcomes in the treatment group, experimental approaches that directly compare outcomes in the treatment and control groups are not applicable. Pseudo-experimental approaches such as the DiD, which control for biases in estimates that occur because of omitted or unobserved variables, are more suitable for the purpose.

\section{Evaluation of outcomes using difference-in-difference technique}

Where there maybe concerns whether the randomisation resulted in a balanced sample, the DiD estimator is unbiased because any pretreatment difference between the treatment and control groups is removed by differencing (differencing away the threat). The DiD method mimics an experimental

1.These tests were first proposed by Rosenbaum and Rubin (1985), who suggested that researchers should examine whether the observable characteristics of the population are independent of participation conditional on the propensity score. research design using observational study data, to study the differential effect of an intervention on a treatment group as compared with a control group in a natural experiment. The effect of a treatment on an outcome is estimated by comparing the average change over time in the outcome variable for the treatment group with the average change over time for the control group. The change which occurs in the control group is an estimate of the true counterfactual, that is, it gives the change that would have occurred to the treatment group had the intervention not been implemented which is the net effect. Following Abadie (2005), the treatment effect is given by the difference between the observed outcome in the treatment group and the trend.

\section{Evaluation of outcomes using difference-in- difference with matching technique}

An important assumption of the DiD approach is the lack of 'parallel trends' or 'common trends' in the two groups (treatment and control) prior to the intervention or treatment. This means that the average change in outcome variable would be the same for the two groups in absence of the treatment. So, while the $\mathrm{DiD}$ approach is powerful for removing or differencing out the differences in the two groups being compared, it is inappropriate where there are common trends (common to treatment effect) over the campaign period.

The differences in outcomes prior to the intervention (at the baseline) and lack of data for at least two pretreatment periods give no confidence to assume or to rule out the presence of 'common trends', which is an important assumption when using the DiD approach. An alternative technique, 'difference in difference with matching', may be used when there are unobserved factors influencing outcomes in the treatment group, and also when common trends cannot be ruled out. In this technique, the comparison 'control' group is limited to households or individuals with an equal likelihood of being treated or falling in the treatment group.

\section{Evaluation of outcomes using doubly robust estimation}

Doubly robust estimation is of interest because it addresses the potential existence of selection bias and results are robust. Two approaches are combined in estimation of the causal effect of an exposure to an outcome. It builds on the propensity score approach and the inverse probability of weighting approach. The effect estimator is robust to misspecification of one of the models because the outcome regression is combined with weighting by the propensity score with regression model of the relationship between covariates and treatment (Bang \& Robins 2005; Robins, Hernan \& Brumback 2000; Robins, Rotnitzky \& Zhao 1994; Robins et al. 2007). The effect of the exposure on the outcome is correctly estimated if the propensity score model or the outcome regression model is correctly specified with an assumption that there are no unmeasured confounders 
(Bang \& Robins 2005; Robins 2000; Robins et al. 1994; Van der Laan \& Robins 2003).

Outcome and exposure models as a function of covariates were specified, and in this case there are two exposure groups (treatment and control groups) and several outcomes (awareness, attitude, perception, knowledge, acreage under maize and production yield, among others). The propensity score was estimated first. In this model, all estimators are generalised method of estimators (GMM). In this study, the outcomes are continuous variables, whereas the exposure is a binary variable; therefore, we used identity link and logit link, respectively. The analysis was conducted using bootstrap and no bootstrap. Funk et al. (2011) recommends reporting the bootstrapped estimates of the standard error and confidence levels because they provide a nominal coverage across sample sizes.

\section{Data}

Data were collected at the baseline and again at the midline from the same households (panel data). The midline survey was conducted 1 year after commencement of the seed promotion campaign (between mid-November 2015 and early February 2016), and captured data from two seasons into the promotion campaign, namely Season 2 in 2014 and Season 1 in 2015. The baseline data were collected before commencement of the promotion campaign and captured data from seasons prior to the promotion campaign. Information sought included household and farm characteristics, farmer awareness and knowledge, farmers' attitudes, perceptions and decision-making with regard to the use of new varieties. Information on farmers' use of improved varieties and acreage planted with the new variety, the yields obtained and other benefits were also collected. Data were also collected from an adult male and female in each household which allowed engendering of some of the information such as attitudes and perceptions. Data on crop production practices were collected at the plot level. The data were collected using tablets and the structured questionnaires were coded using open data kit (ODK). The Statistical Package for Social Sciences (SPSS) was used in cleaning and handling data, while STATA was used in the DiD analysis, matching and doubly robust estimation.

\section{Sample size}

Sample size calculations (performed at baseline) were based on a minimum differential in adoption rate of the treatment group over that of the control group of $10 \%, 80 \%$ power using standard statistical tests which were based on a two-sided significance of $5 \%$ probability of Type I error. Because the households were sampled from village clusters, the calculations were controlled for intra-cluster correlation and attrition (20\% over the 4 -year study period). The required sample size to detect a minimal change of $10 \%$ in the primary indicators was 2162-2770 households depending on the indicator. A stratified random sampling procedure was followed in selecting the households to be interviewed over the entire study period. Villages were randomly chosen from the randomly selected sub-counties. Lists were drawn of these villages, and 14 villages were randomly drawn from each sub-county, which translated to 56 villages from each district totalling to 224 villages. The third stage households to be interviewed were randomly selected using Uganda Bureau of Statistics (UBOS) census data. The targeted number of households to be interviewed in each village was 10 out of the 15 that had been selected from each village. The final calculated sample comprised 2240 households.

At the midline, follow-up interviews were conducted in the same households which were identified at the baseline. The sample size for the midline survey was $2133^{2}$ households, comprising 1853 male- and 280 female-headed households. Of the 2133 households interviewed, only 2020 households were interviewed in both baseline and midline surveys.

\section{Attrition}

There were 2133 households interviewed during each round of survey, but only 2020 households were in both baseline and midline surveys; therefore, there are 2020 households in the panel. A total of 113 households were not interviewed in both baseline and midline surveys (attrition) because they could not be reached for various reasons. Checks for differential attrition and self-selection in the dropouts showed that the households that dropped out of the control and treatment groups were similar in most aspects except asset value, distance to a seller of improved seed, distance to seller of improved seed and distance to agro-dealer. The implication of these results is that there may have been differential attrition; however, a comparison of those who dropped out with the baseline (by group) showed no differences. This means the differences noted were because of the already existing differences at baseline and not because of differential attrition.

\section{Ethical considerations, trustworthiness and validity}

The district and sub-county agricultural officers were approached for permission to conduct surveys in their respective areas. The village elders were also consulted and they assisted in identifying the households selected for the survey. Respondents were asked for consent before proceeding with survey with interviewers, emphasising that participation is voluntary. There are no major ethical issues arising from sampling in this experiment as areas were included or excluded in the promotion campaign based on available resources for the promotion.

\section{Results}

In this section, results from two analytical approaches are presented and discussed. The estimates show changes that occurred during the first year (two seasons of promotions), where results for Season 2 refer to the first season of 2.A household size of 2133 is well within the calculated sample size which allows for an attrition rate of $20 \%$ per year. 
promotions (October 2014-January 2015), results for Season 1 refer to the second season of promotions (March 2015September 2015) and the overall changes refer to the first year of promotion.

\section{Results from difference in differences with matching}

Tables 2, 3 and 4 show the status in outcomes at the baseline and midline, and the difference in outcomes that can be attributed to the seed promotion campaign which comprised demonstration plots and field days (intervention).

\section{Changes and impact on awareness about improved seed}

At the midline, female farmers' awareness about improved seed increased. The proportion of farmers who were aware about improved seed in general increased to $88 \%$ and $89 \%$ in the treatment and control groups, respectively. The proportion of farmers who were aware about improved maize seed increased to $87 \%$ and $85 \%$ in the treatment and control groups, respectively.

At the midline, male farmers' awareness about improved seed appears to have increased. The proportion of farmers who were aware about improved seed in general increased to $77 \%$ and $72 \%$ in the treatment and control groups, respectively. The proportion of farmers who were aware about improved maize seed increased to $96 \%$ and $93 \%$ in the treatment and control groups, respectively. However, the DiD results show no difference between treatment and control groups in general awareness on improved seed or improved maize seed. Similarly, the double robust regression results showed no difference in awareness on improved seed or improved maize seed.

Midline results show that female farmers' attitude towards improved maize varieties improved. However, females in the treatment group had a less positive attitude towards improved maize varieties (less positive by 0.061 points). Male farmers in the treatment group had a less positive attitude towards maize varieties (by 0.05 points). The midline result shows a decline in male and female farmers' knowledge about the two varieties being promoted and also shows no difference in knowledge between the two groups.

\section{Changes and impact on household use and demand for improved seed}

As shown in Table 4, the proportion of households that purchased improved maize seed increased to $31 \%$ and $28 \%$ in the treatment and control groups, respectively, in the first season, and to $22 \%$ in the treatment group in the second season. However, there was no difference between the treatment and comparison groups. The proportion of farmers who planted PH5052 did not change from zero, and there was no difference between the treatment and comparison groups. The acreage planted with the variety did not change either.

The results show the following: no change in acreage planted under unrecycled maize seed in Season 2 and no difference

TABLE 2: Results from difference in differences with matching - Female farmers.

\begin{tabular}{|c|c|c|c|c|c|c|c|c|}
\hline \multirow[t]{2}{*}{ Variable } & & \multicolumn{3}{|c|}{ Baseline } & \multicolumn{3}{|c|}{ Midline } & \multirow[t]{2}{*}{ Diff-in-diff } \\
\hline & & Control & Treatment & Diff & Control & Treatment & Diff & \\
\hline \multirow{6}{*}{$\begin{array}{l}\text { Sources of } \\
\text { information on } \\
\text { improved seeds }\end{array}$} & Demonstration plots & 0.02 & 0.03 & $0.016(0.008)^{*}$ & 0.03 & 0.02 & $-0.003(0.009)$ & $-0.019(0.012)$ \\
\hline & Brochures & 0.00 & 0.01 & $0.001(0.003)$ & 0.00 & 0.03 & $0.003(0.003)$ & $0.002(0.004)$ \\
\hline & Field days & 0.00 & 0.00 & $0.001(0.004)$ & 0.01 & 0.01 & $0.003(0.004)$ & $0.002(0.005)$ \\
\hline & Radio & 0.19 & 0.19 & $-0.004(0.022)$ & 0.23 & 0.27 & $0.039(0.022)^{*}$ & $0.043(0.031)$ \\
\hline & Personal communication & 0.41 & 0.40 & $-0.009(0.025)$ & 0.79 & 0.69 & $-0.097(0.025)^{* * *}$ & $-0.088(0.035)^{* *}$ \\
\hline & $N$ & 561 & 1037 & - & 519 & 1002 & - & - \\
\hline \multirow[t]{4}{*}{$\begin{array}{l}\text { Awareness about } \\
\text { improved seed }\end{array}$} & $\begin{array}{l}\text { Awareness about improved } \\
\text { seed }\end{array}$ & 0.62 & 0.60 & $-0.014(0.022)$ & 0.89 & 0.88 & $-0.01(0.023)$ & $0.004(0.031)$ \\
\hline & $N$ & 561 & 1037 & - & 519 & 1002 & - & - \\
\hline & $\begin{array}{l}\text { Awareness of improved } \\
\text { maize seed }\end{array}$ & 0.73 & 0.75 & $0.018(0.024)$ & 0.85 & 0.87 & $0.018(0.022)$ & $0(0.033)$ \\
\hline & $N$ & 420 & 755 & - & 460 & 878 & - & - \\
\hline \multirow{4}{*}{$\begin{array}{l}\text { Improved maize the } \\
\text { farmer is aware of }\end{array}$} & Aware of $\mathrm{PH} 5052$ & 0.00 & 0.00 & $0.001(0.05)^{* * *}$ & 0.00 & 0.02 & $0.014(0.005)$ & $0.013(0.048)^{* *}$ \\
\hline & Aware of Longe5 & 0.28 & 0.30 & $0.024(0.025)$ & 0.51 & 0.51 & $0.001(0.026)$ & $-0.023(0.036)$ \\
\hline & Aware of Longe 4 & 0.01 & 0.01 & $-0.009(0.012) P$ & 0.13 & 0.01 & $10.033(0.015)$ & $10.024(0.021)$ \\
\hline & $N$ & 561 & 1037 & - & 519 & 1002 & - & - \\
\hline \multirow{2}{*}{$\begin{array}{l}\text { Attitude towards } \\
\text { improved maize } \\
\text { and beans }\end{array}$} & $\begin{array}{l}\text { Attitude towards } \\
\text { improved maize seed }\end{array}$ & 0.70 & 0.73 & $0.029(0.017)^{*}$ & 0.78 & 0.75 & $-0.032(0.017)^{*}$ & $-0.061(0.024)^{* *}$ \\
\hline & $N$ & 418 & 748 & - & 401 & 773 & - & - \\
\hline \multirow[t]{2}{*}{ Perception } & $\begin{array}{l}\text { Perception towards } \\
\text { improved maize varieties }\end{array}$ & 3.11 & 3.19 & $0.082(0.217)$ & 3.27 & 3.11 & $-0.16(0.176)$ & $-0.242(0.28)$ \\
\hline & $N$ & 15 & 26 & - & 17 & 97 & - & - \\
\hline \multirow[t]{2}{*}{ Knowledge } & Knowledge about PH5052 & 0.35 & 0.36 & $0.014(0.082)$ & 0.25 & 0.28 & $0.028(0.064)$ & $0.014(0.104)$ \\
\hline & $N$ & 14 & 23 & - & 17 & 97 & - & - \\
\hline
\end{tabular}

Note: Standard errors in parenthesis.

Diff-in-diff: difference in differences.

$*, * *$ and $* * *$ imply significance at $10 \%, 5 \%$ and $1 \%$, respectively. 
TABLE 3: Results from difference in differences with matching - Male farmers.

\begin{tabular}{|c|c|c|c|c|c|c|c|c|}
\hline \multirow[t]{2}{*}{ Variable } & & \multicolumn{3}{|c|}{ Baseline } & \multicolumn{3}{|c|}{ Midline } & \multirow[t]{2}{*}{ Diff-in-diff } \\
\hline & & Control & Treatment & Diff & Control & Treatment & Diff & \\
\hline \multirow{6}{*}{$\begin{array}{l}\text { Sources of } \\
\text { information on } \\
\text { improved seeds }\end{array}$} & Demonstration plots & 0.03 & 0.04 & $0.02(0.01)$ & 0.04 & 0.06 & $0.02(0.01)$ & $0(0.02)$ \\
\hline & Brochures & 0.00 & 0.00 & $0(0.00)$ & 0.00 & 0.01 & $0(0.00)$ & $0(0.01)$ \\
\hline & Field days & 0.01 & 0.01 & $0(0.01)$ & 0.01 & 0.01 & $0(0.01)$ & $0(0.01)$ \\
\hline & Radio & 0.20 & 0.24 & $0.04(0.02)^{*}$ & 0.28 & 0.32 & $0.04(0.02)^{*}$ & $0(0.03)$ \\
\hline & Personal communication & 0.37 & 0.40 & $0.03(0.03)$ & 0.66 & 0.60 & $-0.07(0.03)^{* *}$ & $-0.1(0.04) * * *$ \\
\hline & $N$ & 565 & 1034 & - & 520 & 1003 & - & - \\
\hline \multirow{4}{*}{$\begin{array}{l}\text { Awareness about } \\
\text { improved seed }\end{array}$} & Awareness of improved seed & 0.55 & 0.58 & $0.03(0.02)$ & 0.72 & 0.77 & $0.04(0.03)^{*}$ & $0.01(0.04)$ \\
\hline & $N$ & 565 & 1034 & - & 520 & 1003 & - & - \\
\hline & $\begin{array}{l}\text { Awareness about improved } \\
\text { maize seed }\end{array}$ & 0.82 & 0.87 & $0.05(0.02)^{* *}$ & 0.93 & 0.96 & $0.03(0.02)^{*}$ & $-0.02(0.03)$ \\
\hline & $N$ & 353 & 659 & - & 376 & 767 & - & - \\
\hline \multirow{4}{*}{$\begin{array}{l}\text { Improved maize the } \\
\text { farmer is aware of }\end{array}$} & Aware of PH5052 & 0.00 & 0.01 & $0.01(0.01)$ & 0.01 & 0.03 & $0.01(0.01)^{* *}$ & $0.01(0.01)$ \\
\hline & Aware of Longe 5 & 0.30 & 0.35 & $0.05(0.03)^{* *}$ & 0.53 & 0.58 & $0.05(0.03)^{*}$ & $0(0.04)$ \\
\hline & Aware of Longe4 & 0.10 & 0.09 & $-0.01(0.02)$ & 0.16 & 0.17 & $0.01(0.02)$ & $0.02(0.03)$ \\
\hline & $N$ & 565 & 1034 & - & 520 & 1003 & - & - \\
\hline \multirow{2}{*}{$\begin{array}{l}\text { Attitude towards } \\
\text { improved maize } \\
\text { and beans }\end{array}$} & $\begin{array}{l}\text { Attitude towards improved } \\
\text { maize seed }\end{array}$ & 0.76 & 0.78 & $0.02(0.02)$ & 0.77 & 0.76 & $-0.01(0.02)$ & $-0.04(0.03)$ \\
\hline & $N$ & 352 & 649 & - & 364 & 748 & - & - \\
\hline \multirow[t]{2}{*}{ Perception } & $\begin{array}{l}\text { Perception towards improved } \\
\text { maize varieties }\end{array}$ & 3.09 & 3.14 & $0.05(0.2)$ & 2.92 & 3.21 & $0.29(0.1)^{* * *}$ & $0.24(0.22)$ \\
\hline & $N$ & 16 & 37 & - & 63 & 167 & - & - \\
\hline \multirow[t]{2}{*}{ Knowledge } & Knowledge about PH5052 & 0.40 & 0.43 & $0.03(0.1)$ & 0.21 & 0.26 & $0.05(0.04)$ & $0.02(0.11)$ \\
\hline & $N$ & 8 & 32 & - & 63 & 166 & - & - \\
\hline
\end{tabular}

Note: Standard errors in parenthesis.

Diff-in-diff: difference in differences.

$*, * *$ and $* * *$ imply significance at $10 \%, 5 \%$ and $1 \%$, respectively.

TABLE 4: Results from difference in difference with matching - Household Level.

\begin{tabular}{|c|c|c|c|c|c|c|c|c|}
\hline \multirow[t]{2}{*}{ Variable } & \multirow[t]{2}{*}{ Outcome } & \multicolumn{3}{|c|}{ Baseline } & \multicolumn{3}{|c|}{ Midline } & \multirow[t]{2}{*}{ Diff-in-diff } \\
\hline & & Control & Treatment & Diff & Control & Treatment & Diff & \\
\hline \multirow{4}{*}{$\begin{array}{l}\text { Acreage under } \\
\text { PH5052 }\end{array}$} & Acres under PH5052 Season 1 & 0.00 & 0.00 & $0.002(0.011)$ & 0.02 & 0.00 & $-0.021(0.012)^{*}$ & $-0.023(0.016)$ \\
\hline & Acres under PH5052 Season 2 & 0.00 & 0.00 & $0.002(0.002)$ & 0.00 & 0.00 & $0.002(0.002)$ & $-0.000(0.003)$ \\
\hline & Acres under PH5052 all seasons & 0.00 & 0.00 & $0.004(0.012)$ & 0.02 & 0.00 & $-0.019(0.012)$ & $-0.023(0.017)$ \\
\hline & $N$ & 562 & 1036 & - & 519 & 1002 & - & - \\
\hline \multirow{3}{*}{$\begin{array}{l}\text { Proportion of } \\
\text { farmers who } \\
\text { planted PH5052 }\end{array}$} & $\begin{array}{l}\text { Proportion that planted } \mathrm{PH} 5052 \\
\text { Season } 1\end{array}$ & 0.00 & 0.00 & $0.002(0.002)$ & 0.00 & 0.00 & $0.001(0.002)$ & $-0.001(0.003)$ \\
\hline & $\begin{array}{l}\text { Proportion that planted PH5052 } \\
\text { Season } 2\end{array}$ & 0.00 & 0.00 & $0.003(0.002)$ & 0.00 & 0.00 & $0.002(0.002)$ & $-0.001(0.003)$ \\
\hline & $N$ & 562 & 1036 & - & 519 & 1002 & - & - \\
\hline \multirow{3}{*}{$\begin{array}{l}\text { Proportion of } \\
\text { farmers who } \\
\text { purchased } \\
\text { improved maize } \\
\text { and bean seed }\end{array}$} & $\begin{array}{l}\text { Proportion that purchased } \\
\text { improved maize seed Season } 1\end{array}$ & 0.24 & 0.26 & $0.026(0.023)$ & 0.28 & 0.31 & $0.031(0.024)$ & $0.005(0.034)$ \\
\hline & $\begin{array}{l}\text { Proportion that purchased } \\
\text { improved maize seed Season } 2\end{array}$ & 0.18 & 0.21 & $0.031(0.021)$ & 0.18 & 0.22 & $0.035(0.022)$ & $0.004(0.030)$ \\
\hline & $N$ & 562 & 1036 & - & 519 & 1002 & - & - \\
\hline \multirow{10}{*}{$\begin{array}{l}\text { Acreage planted } \\
\text { with type of } \\
\text { maize seed }\end{array}$} & $\begin{array}{l}\text { Acres unrecycled improved } \\
\text { maize Season } 1\end{array}$ & 0.31 & 0.37 & $-0.060(0.051)$ & 0.43 & 0.41 & $-0.015(0.053)$ & $-0.075(0.074)$ \\
\hline & $\begin{array}{l}\text { Acres recycled improved maize } \\
\text { Season } 1\end{array}$ & 0.18 & 0.19 & $0.006(0.039)$ & 0.35 & 0.28 & $-0.075(0.040)$ & $-0.081(0.056)$ \\
\hline & $\begin{array}{l}\text { Acres local improved maize } \\
\text { Season } 1\end{array}$ & 0.05 & 0.03 & $-0.020(0.026)$ & 0.41 & 0.35 & $-0.058(0.027)^{* *}$ & $-0.038(0.037)$ \\
\hline & $\begin{array}{l}\text { Acres unrecycled local maize } \\
\text { Season } 1\end{array}$ & 0.43 & 0.43 & $0.003(0.035)$ & 0.00 & 0.01 & $0.006(0.036)$ & $0.003(0.051)$ \\
\hline & $\begin{array}{l}\text { Acres unrecycled improved } \\
\text { maize Season } 2\end{array}$ & 0.24 & 0.31 & $0.077(0.046)$ & 0.29 & 0.29 & $0.008(0.048)$ & $-0.069(0.066)$ \\
\hline & $\begin{array}{l}\text { Acres recycle improved maize } \\
\text { Season } 2\end{array}$ & 0.14 & 0.15 & $0.003(0.037)$ & 0.36 & 0.29 & $-0.068(0.038)^{*}$ & $-0.072(0.053)$ \\
\hline & Acres local maize Season 2 & 0.03 & 0.02 & $-0.006(0.024)$ & 0.34 & 0.34 & $-0.004(0.025)$ & $0.002(0.035)$ \\
\hline & $\begin{array}{l}\text { Acres unrecycled local maize } \\
\text { Season } 2\end{array}$ & 0.36 & 0.34 & $-0.018(0.032)$ & 0.00 & 0.01 & $0.001(0.033)$ & $0.019(0.046)$ \\
\hline & $\begin{array}{l}\text { Acres unrecycled improved } \\
\text { maize season all }\end{array}$ & 0.59 & 0.69 & $0.137(0.084)$ & 0.71 & 0.71 & $-0.007(0.087)$ & $-0.144(0.121)$ \\
\hline & $\begin{array}{l}\text { Acres recycle improved maize } \\
\text { season all }\end{array}$ & 0.32 & 0.33 & $0.009(0.062)$ & 0.71 & 0.57 & $-0.144(0.064)^{* *}$ & $-0.153(0.088) *$ \\
\hline
\end{tabular}


TABLE 4 (Continues...): Results from difference in difference with matching - Household Level.

\begin{tabular}{|c|c|c|c|c|c|c|c|c|}
\hline \multirow[t]{2}{*}{ Variable } & \multirow[t]{2}{*}{ Outcome } & \multicolumn{3}{|c|}{ Baseline } & \multicolumn{3}{|c|}{ Midline } & \multirow[t]{2}{*}{ Diff-in-diff } \\
\hline & & Control & Treatment & Diff & Control & Treatment & Diff & \\
\hline & $N$ & 562 & 1036 & - & 519 & 1002 & - & - \\
\hline \multirow{4}{*}{$\begin{array}{l}\text { Maize production } \\
\text { and yield }\end{array}$} & Acreage under maize & 2.09 & 1.97 & $-0.115(0.125)$ & 2.19 & 1.99 & $-0.205(0.129)$ & $-0.090(0.180)$ \\
\hline & Production of maize $(\mathrm{kg})$ & 1039.27 & 1054.30 & $15.030(126.614)$ & 1100.43 & 1098.43 & $-1.993(130.704)$ & $-17.024(181.974)$ \\
\hline & $N$ & 562 & 1036 & - & 519 & 1002 & - & - \\
\hline & Yield of maize (kg/acre) & 449.95 & 501.88 & $51.93(31.580)$ & 490.13 & 509.953 & $19.822(31.673)$ & $-32.106(44.726)$ \\
\hline \multirow{4}{*}{$\begin{array}{l}\text { Acreage under } \\
\text { maize and beans }\end{array}$} & Acres under maize Season 1 & 0.96 & 1.00 & $0.040(0.065)$ & 1.20 & 1.06 & $-0.143(0.068)^{* *}$ & $-0.183(0.094) *$ \\
\hline & Acres under maize Season 2 & 0.76 & 0.81 & $0.056(0.063)$ & 0.99 & 0.93 & $-0.063(0.065)$ & $-0.119(0.090)$ \\
\hline & Acres under maize all seasons & 1.72 & 1.81 & $0.096(0.109)$ & 2.19 & 2.00 & $-0.205(0.112)^{*}$ & $-0.301(0.156)^{*}$ \\
\hline & $N$ & 562 & 1036 & - & 519 & 1002 & - & - \\
\hline
\end{tabular}

Note: Standard errors in parenthesis.

Diff-in-diff: difference in differences.

$*, * *$ and $* * *$ imply significance at $10 \%, 5 \%$ and $1 \%$, respectively.

TABLE 5: Results from double robust estimate - Individual level (male and female).

\begin{tabular}{|c|c|c|c|c|}
\hline \multirow[t]{3}{*}{ Variable } & \multicolumn{4}{|c|}{ Double robust with bootstrap (bootstrap replications $=50$ ) } \\
\hline & \multicolumn{2}{|c|}{ Outcome and exposure } & \multicolumn{2}{|c|}{ Exposure } \\
\hline & Male & Female & Male & Female \\
\hline Awareness of improved seed & $-0.0003(0.016)$ & $0.017(0.024)$ & $-0.002(0.021)$ & $0.012(0.017)$ \\
\hline$N$ & 686 & 1818 & 686 & 1818 \\
\hline Awareness of improved maize seed & $0.017(0.024)$ & $0.008(0.026)$ & $0.015(0.022)$ & $0.005(0.027)$ \\
\hline$N$ & 1128 & 1373 & 1128 & 1373 \\
\hline Attitude towards improved maize seed & $0.056(0.02) * *$ & $0.044(0.018) * *$ & $0.056(0.018) * * *$ & $0.037(0.025)^{* *}$ \\
\hline$N$ & 1083 & 1208 & 1083 & 1208 \\
\hline Perception towards improved maize varieties & $0.073(0.667)$ & $\mathrm{Nd}$ & $0.274(0.473)$ & $\mathrm{Nd}$ \\
\hline$N$ & 13 & & 13 & \\
\hline Knowledge about PH5052 & $0.157(0.427)$ & $\mathrm{Nd}$ & $0.027(0.254)$ & $\mathrm{Nd}$ \\
\hline$N$ & 19 & & 19 & \\
\hline
\end{tabular}

Note: Standard errors in parenthesis.

$\mathrm{Nd}$, no enough data for regression, only two cases; Diff-in-diff, difference in differences.

$*, * *$ and $* * *$ imply significance at $10 \%, 5 \%$ and $1 \%$, respectively.

between treatment and control groups; an increase in acreage under recycled maize seed in Season 2 to 0.29 and 0.36 acres in treatment and control groups, respectively, and no difference between the two groups; an increase in acreage under local maize seed in Season 2 to 0.34 acres in both treatment and control groups, but no differences were found between the two groups.

\section{Changes and impact on maize production}

Midline results show an increase in acreage planted with maize in the treatment and control groups, to 2 and 2.19 acres respectively, and DiD results show that households in the treatment group allocated less acreage to maize (less by 0.3 acres). The volume of maize produced increased to $1098 \mathrm{~kg}$ and $1100 \mathrm{~kg}$ in treatment and control groups, but DiD results showed no difference between the treatment and control groups. Similarly, the yield of maize increased to $510 \mathrm{~kg}$ and $490 \mathrm{~kg}$ in treatment and control groups, respectively, but $\mathrm{DiD}$ results showed no difference between the groups.

\section{Results from double robust estimation}

\section{Changes in awareness, attitude, perception and knowledge among male and female farmers}

The results presented in Table 5 show an improvement in attitude towards improved maize seed of $6 \%$ and $4 \%$ among male and female respondents, respectively. However, there was no difference in awareness, perception and knowledge about the promoted variety (PH5052) among the male or female respondents.

\section{Change in proportion and acreage planted with improved seed, maize yield and production}

The results in Table 6 show there was a $16 \%$ decline in acreage planted under maize during the second season. The acreage planted under local maize seed also declined by $13 \%$ in Season 2 and by 18\% over the two seasons (annual). There was no change in the acreage of maize planted in Season 1 , in acreage planted under the variety that was being promoted (PH5052), in the proportion of farmers who planted improved maize seed, in the proportion of farmers who purchased improved seed and in maize production or yield.

\section{Conclusions}

This study documents and assesses the effects of demonstration plots and field days on farmers' awareness, attitude, perception, knowledge, use and demand for an improved maize variety seed that was being promoted in eastern and western Uganda. The findings of this study indicate that there were changes in some aspects such as farmers' perception about the improved variety being promoted. However, no change occurred in farmers' 
TABLE 6: Results from doubly robust estimate - Household level.

\begin{tabular}{|c|c|c|c|}
\hline \multirow[t]{2}{*}{ Outcome } & \multirow[t]{2}{*}{ Variable } & \multicolumn{2}{|c|}{$\begin{array}{l}\text { Doubly (bootstrap } \\
\text { replications }=50)(N=1839)\end{array}$} \\
\hline & & $\begin{array}{l}\text { Outcome and } \\
\text { exposure }\end{array}$ & Exposure \\
\hline \multirow{2}{*}{$\begin{array}{l}\text { Acres under } \\
\text { maize }\end{array}$} & Acres under maize Season 1 & $-0.1(0.1)$ & $-0.1(0.1)$ \\
\hline & Acres under maize season 2 & $-0.16(0.08) * *$ & $-0.17(0.09) * *$ \\
\hline \multirow{3}{*}{$\begin{array}{l}\text { Acres under } \\
\text { PH5052 }\end{array}$} & Acres under PH5052 Season 1 & $-0.03(0.13)$ & $-0.03(0.11)$ \\
\hline & Acres under PH5052 Season 2 & $-0.01(0.01)$ & $-0.01(0.01)$ \\
\hline & $\begin{array}{l}\text { Acres under PHh5052 all } \\
\text { seasons }\end{array}$ & $0.00(0.00)$ & $0.00(0.00)$ \\
\hline \multirow{2}{*}{$\begin{array}{l}\text { Proportion } \\
\text { that planted } \\
\text { PH5052 }\end{array}$} & $\begin{array}{l}\text { Proportion that planted } \\
\text { PH5052 Season } 1\end{array}$ & $-0.01(0.01)$ & $-0.01(0.01)$ \\
\hline & $\begin{array}{l}\text { Proportion that planted } \\
\text { PH5052 Season } 2\end{array}$ & $0.00(0.00)$ & $0.00(0.00)$ \\
\hline \multirow[t]{2}{*}{$\begin{array}{l}\text { Proportion } \\
\text { that improved } \\
\text { maize seed }\end{array}$} & $\begin{array}{l}\text { Proportion that purchased } \\
\text { improved maize seed } \\
\text { Season } 1\end{array}$ & $0.00(0.00)$ & $0.00(0.00)$ \\
\hline & $\begin{array}{l}\text { Proportion that purchased } \\
\text { improved maize seed Season } 2\end{array}$ & $-0.02(0.03)$ & $-0.02(0.02)$ \\
\hline \multirow{13}{*}{$\begin{array}{l}\text { Acres under } \\
\text { improved } \\
\text { maize seed }\end{array}$} & $\begin{array}{l}\text { Acres unrecycled improved } \\
\text { maize Season } 1\end{array}$ & $0.01(0.02)$ & $0.01(0.02)$ \\
\hline & $\begin{array}{l}\text { Acres recycled improved } \\
\text { maize Season } 1\end{array}$ & $-0.07(0.11)$ & $-0.07(0.09)$ \\
\hline & $\begin{array}{l}\text { Acres local improved maize } \\
\text { Season } 1\end{array}$ & $-0.05(0.05)$ & $-0.05(0.04)$ \\
\hline & $\begin{array}{l}\text { Acres unrecycled local maize } \\
\text { Season } 1\end{array}$ & $0.01(0.03)$ & $0.00(0.04)$ \\
\hline & $\begin{array}{l}\text { Acres unrecycled improved } \\
\text { maize Season } 2\end{array}$ & $0.01(0.05)$ & $0.02(0.04)$ \\
\hline & $\begin{array}{l}\text { Acres recycle improved maize } \\
\text { Season } 2\end{array}$ & $-0.08(0.06)$ & $-0.08(0.04)$ \\
\hline & $\begin{array}{l}\text { Acres under local maize } \\
\text { Season } 2\end{array}$ & $-0.13(0.06)^{* * *}$ & $-0.13(0.06)^{* * *}$ \\
\hline & $\begin{array}{l}\text { Acres unrecycled local maize } \\
\text { Season } 2\end{array}$ & $0.01(0.03)$ & $0.01(0.03)$ \\
\hline & $\begin{array}{l}\text { Acres unrecycled improved } \\
\text { maize season all }\end{array}$ & $0.03(0.04)$ & $0.03(0.03)$ \\
\hline & $\begin{array}{l}\text { Acres recycle improved maize } \\
\text { season all }\end{array}$ & $-0.15(0.12)$ & $-0.15(0.13)$ \\
\hline & $\begin{array}{l}\text { Acres under local maize } \\
\text { season all }\end{array}$ & $-0.18(0.08)^{* * *}$ & $-0.18(0.09) * *$ \\
\hline & $\begin{array}{l}\text { Acres unrecycled improved } \\
\text { maize season all }\end{array}$ & $0.02(0.06)$ & $0.01(0.06)$ \\
\hline & Acreage under maize & $0.04(0.07)$ & $0.04(0.07)$ \\
\hline \multirow{2}{*}{$\begin{array}{l}\text { Maize production } \\
\text { and yield }\end{array}$} & Production of maize $(\mathrm{kg})$ & $0.00(0.00)$ & $0.00(0.00)$ \\
\hline & Yield of maize (kg/acre) & $-46.72(35.86)$ & $-52.35(50.78)$ \\
\hline
\end{tabular}

awareness or knowledge about the variety being promoted (PH5052). Similar results were obtained for male and female farmers. Very few farmers were using the variety and the acreage planted with the variety did not change.

Interestingly, although there was no change in use of the specific variety being promoted, the promotion campaign caused a positive adoption behaviour as shown in the marked reduction in acreage planted with local maize seed or in acreage planted with recycled improved seed. The interventions had no impact on production and yield of maize.

The conclusion, therefore, is that the demonstration plots and field days mounted by the seed company to promote the new seed variety had no impact on the awareness and knowledge of varieties promoted. There was also no impact on farmers' adoption of the maize varieties, and consequently no impact on the yield or production of maize.
Considering the slow pace of adoption of improved seed in SSA, it may be too early to expect changes in adoption of the newly introduced variety. It is also necessary to introduce new or innovative approaches of creating awareness and promoting new seed that can fast track the uptake of new varieties. Seed companies and nongovernmental organisations urgently need promotion approaches that are more effective and can trigger faster adoption of new improved varieties. Further studies on farmers' adoption behaviour are also needed, such as mapping of information and knowledge flow to farmers and addressing institutional constraints which hinder information flow and seed uptake.

\section{Limitations of the study}

The findings may have been influenced by the constraints or challenges faced by the seed company in rolling out the promotion campaign as agreed. These constraints include delays in rainfall, inadequate rain, destruction of demo plots by livestock, poor or incorrect labelling and destruction of sign boards at demo, unavailability of the demo hosts at their plots to answer other farmers' queries about the new varieties and poor turnout during field days.

\section{Acknowledgements}

We wish to thank the farmers who contributed data and information used in this report. We are also grateful to the Alliance for a Green Revolution in Africa (AGRA), for providing an opportunity to undertake this impact evaluation study and for their support in its implementation. Special thanks to the Director of Tegemeo Institute for support and facilitation of the study team while undertaking the study, and to the team from Pearl Seed Limited, for their collegial attitude and interest in the study. The study team also acknowledge the support received from local leaders in the areas of study in Uganda, for providing logistical support during data collection. The hard work and dedication of the research assistants, field supervisors and enumerators is highly acknowledged.

\section{Competing interests}

The authors declare that they have no financial or personal relationships that may have inappropriately influenced them in writing this article.

\section{Authors' contributions}

M.K. was the project leader and principal investigator and was responsible for the research design, project implementation, analysis and writing of the article. F.B. was the co-principal investigator and contributed significantly to the research design, implementation of the project and writing of the article. C.R. contributed significantly to data collection, data analysis and writing of the article. J.M. contributed significantly to data collection and was involved in data analysis and compilation. R.T. contributed significantly to data collection and was involved in transformation of field data. 


\section{References}

Abadie, A., 2005, 'Semiparametric difference-in-differences estimators', The Review of Economic Studies 72(1), 1-19. https://doi.org/10.1111/0034-6527.00321

Adeola, R.G., 2005, 'The impact of training and visit system on professionalization of extension agents in Oyo State Agricultural Development Programme', Journal of Social Sciences 11(3), 193-195. https://doi.org/10.1080/09718923.2005.11892513

Adesina, A.A. \& Baidu-Forson, J., 1995, 'Farmers' perceptions and adoption of new agricultural technology: Evidence from analysis in Burkina Faso and Guinea, West
Africa', Agricultural Economics 13(1), 1-9. https://doi.org/10.1016/0169-5150(95) Africa', Agric
$01142-8$

AGRA, 2013, Africa Agriculture Status Report: Focus on Staple Crops, The Alliance for a Green Revolution in Africa (AGRA), Nairobi, Kenya, viewed 12 May 2016, from www.agra-alliance.org

Amudavi, D.M., Khan, Z.R., Wanyama, J.M., Midega, C.A., Pittchar, J., Hassanali, A. et al., 2009, 'Evaluation of farmers' field days as a dissemination tool for push-pull technology in Western Kenya', Crop Protection 28(3), 225-235. https://doi.org/ 10.1016/j.cropro.2008.10.008

Bang, H. \& Robins, J.M., 2005, 'Doubly robust estimation in missing data and causa inference models', Biometrics 61(4), 962-973. https://doi.org/10.1111/j.1541 0420.2005.00377.x

BenYishay, A. \& Mobarak, A.M., 2013, Communicating with farmers through socia networks, Yale University Economic Growth Centre Discussion Paper (1030), Yale Economics Department Working Paper No. 121, viewed n.d., from https://ssrn. com/abstract $=231522$

Carolan, M.S., 2008, 'Democratizing knowledge: Sustainable and conventional agricultural field days as divergent democratic forms', Science, Technology \& Human Values 33(4), 508-528. https://doi.org/10.1177/0162243907306698

Davis, K., Nkonya, E., Kato, E., Mekonnen, D.A., Odendo, M., Miiro, R. et al., 2012 'Impact of farmer field schools on agricultural productivity and poverty in East Africa', World Development 40(2), 402-413. https://doi.org/10.1016/j.worlddev. 2011.05.019

Friis-Hansen, E. \& Duveskog, D., 2012, 'The empowerment route to well-being: An analysis of farmer field schools in East Africa', World Development 40(2), 414-427. https://doi.org/10.1016/j.worlddev.2011.05.005

Funk, M.J., Westreich, D., Wiesen, C., Stürmer, T., Brookhart, M.A. \& Davidian, M., 2011. 'Doubly robust estimation of causal effects', American Journal of Epidemiology 173(7), 761-767. https://doi.org/10.1093/aje/kwq439

Ghatak, P., 2010, 'Development of mass media and its extension in agriculture: A feedback review of audience research survey in Air, Murshidabad, West Bengal', Global Media Journal, Indian edition I(1), 1, Summer Issue, June 2010.

Green, D.P. \& Vavreck, L., 2008, 'Analysis of cluster-randomized experiments: A comparison of alternative estimation approaches', Political Analysis 16(2), 138-152. https://doi.org/10.1093/pan/mpm025

Hassan, R.M., 1998, Maize technology development and transfer: A GIS application for research planning in Kenya, CIMMYT, KARI, CAB International, Wallingford.

Hartman, E. \& Sp, P., 2010, Clustered Standard Errors.

Heiniger, R., Havlin, J., Crouse, D., Kvien, C. \& Knowles, T., 2002, 'Seeing is believing: The role of field days and tours in precision agriculture education', Precision Agriculture 3(4), 309-318. https://doi.org/10.1023/A:1021532603441

Kabir, H. \& Uphoff, N., 2007, 'Results of disseminating the system of rice intensification with farmer field school methods in Northern Myanmar', Experimental Agriculture 43(4), 463-476. https://doi.org/10.1017/S0014479707005340

Khaila, S., Tchuwa, F., Franze, L.S. \& Simpson, S., 2015, The Farmer-to-Farmer extension approach in Malawi: A survey of lead farmers, ICRAF Working Paper No. 189. World Agroforestry Centre, Nairobi, viewed n.d., from http://www.worldagroforestry.org/ downloads/Publications/PDFS/WP14200.pdf
Khan, A., Pervaiz, U., Khan, N., Ahmad, S. \& Nigar, S., 2009, 'Effectiveness of demonstration on plots as extension method adopted by AKRSP for agricultural technology dissemination in district Chitral', Sarhad Journal of Agriculture 25(2), 313-319.

Knowler, D. \& Bradshaw, B., 2007, 'Farmers' adoption of conservation agriculture: A review and synthesis of recent research', Food Policy 32(1), 25-48. https://doi. org/10.1016/j.foodpol.2006.01.003

Kondylis, F. \& Mueller, V., 2013, Seeing is believing? Evidence from a demonstration plot experiment in Mozambique, Mozambique Strategy Support Program Working Paper No.1, International Food Policy Research Institute (IFPRI), Washington, DC.

Mgbakor, M., Iyobor, O. \& Okezie, U.P., 2013, 'Contributions of mass media to the development of agricultural extension in Ika North East LGA of Delta State, Nigeria', Academic Journal of Plant Sciences 6(3), 127-133.

Munsaka, J.S., 2010, Contextualising Information and Communication Technology for Development (ICT4D) in Zambia, Panos, London.

Musa, Y.N., Aboki, E. \& Audu, I.A., 2013, 'The limitations and implications of Training and Visit (T\&V) extension system in Nigeria', Journal of Agriculture and Sustainability 4(1), 69-70.

Mutz, D. \& Pemantle, R., 2011, The perils of randomization checks in the analysis of experiments, Draft, University of Pennsylania, Philadelphia

Nazari, M.R. \& Hasbullah, A.H., 2010, 'Radio as an educational media: impact on agricultural development', The Journal of the South East Asia Research Centre 2, 13-20.

Robins, J., Sued, M., Lei-Gomez, Q. \& Rotnitzky, A., 2007, 'Comment: Performance of double-robust estimators when "inverse probability" weights are highly variable', Statistical Science 22(4), 544-559. https://doi.org/10.1214/07-STS227D

Robins, J.M., 2000, 'Robust estimation in sequentially ignorable missing data and causal inference models', Proceedings of the American Statistical Association Section on Bayesian Statistical Science, American Statistical Association, Alexandria, VA, Vol. 1999, pp. 6-10.

Robins, J.M., Hernan, M.A. \& Brumback, B., 2000, 'Marginal structural models and causal inference in epidemiology', Journal of Epidemiology 11(5), 550-560.

Robins, J.M., Rotnitzky, A. \& Zhao, L.P., 1994, 'Estimation of regression coefficients when some regressors are not always observed', Journal of the American Statistical Association 89(427), 846-866. https://doi.org/10.1080/01621459.199 4.10476818

Rosenbaum, P.R. \& Rubin, D.B., 1983, 'The central role of the propensity score in observational studies for causal effects', Biometrika 70(1), 41-55. https://doi org/10.1093/biomet/70.1.41

Smale, M. \& Olwande, J., 2011. Is older better?: Maize hybrid change on household farms in Kenya, Food Security International Development Working Papers 118474 Michigan State University, Department of Agricultural, Food, and Resource Economics and Department of Economics, East Lansing, MI.

Solon, O., 2013, 'MFarm empowers Kenya's farmers with price transparency and market access', The Wired Newspaper, viewed 29 June 2016, from http://www. wired.co.uk/news/archive/2013-06/21/mfarm.

Van den Berg, H. \& Jiggins, J., 2007, 'Investing in farmers - The impacts of farmer field schools in relation to integrated pest management', World Development 35(4), 663-686. https://doi.org/10.1016/j.worlddev.2006.05.004

Van der Laan, M.J. \& Robins, J.M., 2003, Unified methods for censored longitudinal data and causality, Springer-Verlag, New York.

Waddington, H., Snilstveit, B., Hombrados, J.G., Vojtkova, M., Anderson, J. \& White, H., 2014, 'Farmer field schools for improving farming practices and farme outcomes in low-and middle-income countries: A systematic review', Campbell Systematic Reviews 10(6).

Zhang, Y., Wang, L. \& Duan, Y., 2016, 'Agricultural information dissemination using ICTs: A review and analysis of information dissemination models in China', Information Processing in Agriculture 3(1), 17-29. https://doi.org/10.1016/j.inpa. 2015.11.002 